\title{
The Integration of Funding Aid, wisdom aid and Ability Aid: Poor Funding of College Students in Transition
}

\author{
Ning WANG \\ NanJing XiaoZhuang University \\ Nanjing, 211171 China
}

\begin{abstract}
The problem of poor students in universities is an important problem facing the development process of popularization of higher education; the poor management of Health-funded universities has been an important part of university student work. Currently, the University of Poor Students has the new features from poverty and economic deprivation to the psychological study of to career planning to help university students. It can help them have clear goals to help funding to help wisdom, to help poor students have the integration of the University to enhance the quality and ability to serve poor students learning to help universities foster a sense of responsibility, and ultimately lead to self-help poor students to get out the difficult.
\end{abstract}

Keywords-University of Poor Students; Career Planning; the Integration of Aid Funding, Wisdom aid and Ability Aid; Service Learning; Self-help

\section{INTRODUCTION}

Poor students of university is the current practice in the field of higher education "merger enrollment" and it can accelerate an important focus after popularization of higher education facing university students in the scale of the expansion of school tuition and lead to poverty. There is also increasing the number of college students. Poor students of university has become common concern from the government, parents, the school and the problem of students with social anxiety, and it even affects the current stability and development of universities. The new changes are implemented to help funding for core funding from the Government and the University of Poor Students currently exists between the uncoordinated, which should pay close attention.

\section{New Features of A PoOr College Students}

Although the data on college students and poor students do not have the exact official data, but it is generally considered that poor students in the school of the University of Proportion has reached more than 20\%. Agriculture, forestry, the proportion of Normal University (College) have reached even more than $30 \%$. More compelling new change is that if the original University of poor students are usually referred to from the perspective of economic poverty identified. Then these economically disadvantaged students has a new feature, through the University of economically disadvantaged students continue follow-up study and observed: these economically disadvantaged students are often accompanied by a "psychological poverty" and "learning poverty" double practical difficulties, "triple poverty" which is becoming a current University of poor students new features.

\section{The DefeCt OF The CURRENT Funding System}

The national university management policy is in an important part of building the "award, help, loan, diligence, complement, free" system that allows poor students benefit from many college students successfully to complete their studies. Especially in recent years, the state increased the national implementation of national awards, making national awards, which grants a funding policy, it has become an honor incentive motivated college students. But it is not suited to the new changes in the current funding system and the difficulties between the University of poor students, there is still a mismatch.

\section{A. Prominent Tendency of Currency}

The current funding system is monetized, and students receive direct funding of currency. Part of the poor students could not withstand the temptation to use the grant funds for the pursuit of material comforts and mobile phones, computers and other items on such funding frustrated desire. Some college students because of funding develop a "overdraft consumption" and "excessive consumption" thinking, and even cause some students to make money by taking proven forged poor to get poor students qualification.

\section{B. Single Funded Dimensions}

In the current university funding system, poor students are direct beneficiaries; there are few recipients of the University for Poor Students to have mandatory requirements and regulations. There is almost no feedback mechanism to track and enforce responsibility for funding the object, the rights and responsibilities of benefit are making some poor college students to have the habit of " rely, wait, and need", it also affects the sense of responsibility of college students to cultivate gratitude and self-conscious awareness.

\section{Funding Is Not Equal to "Love"}

Monetization, materialistic funding policy for poor students in the University in so direct, but it is easy to flow in the temporary and superficial. Monetization and materialism are often a one-time funding with "external transfusionstyle" approach, in addition to poor college students, they want to get financial support, the deeper sub-layer need --"vulnerable psychological care" is their desperate need. 
"Compared with the economic difficulties, vulnerable psychology to the negative effects caused by poor students is more serious, so to meet the need for psychological support poor students whose needs are more important than material support to meet."

\section{TRANSITION FROM AID FUNDS TO WISDOM AID}

University of poor students face new changes in the "economic, academic, psychological", to help poor college students is the core of the current funding system for the academic attention, lack of attention to the need improve aspects of care, so transition from aid funds to wisdom aid seems increasingly important. Wisdom aid builds the core of the funding system that is built around "Rebate - Student Strong Heart," the idea for the poor college students is to achieve "turnaround" to provide assistance, the most prominent role is to help clients achieve his college students to self-help, and then self-reliance, self-confidence changes.

\section{A. Career Education to Help Poor College Students to Build Confidence}

"Three of poverty" in poverty Students are extreme events they encounter in college studying stage, but its impact is far-reaching, so help poor college students build confidence, develop self-confidence and self-esteem is especially important. Career planning in UK, USA, Australia and other developed countries is through the legal form of higher education as a future college students design and development needs of "compulsory". And it is also the ability to bring the career college students, to enhance awareness of entrepreneurship and employability also highlights the tremendous achievements of the national higher education reform and innovation. Currently, a careerplanning course of universities has been implemented, but the operation has been less than satisfactory. For the poor college students who "build the base", for their future, then the career planning education is important, and it is the basic work.

Students have the changes from poor real economic difficulties to the "economic poverty, learning difficulties and mental poor", leading to the University for the future, especially in professional development full of confusion and even fear. The poor college students enter the profession after completing their studies in the field of the future if it is to change the situation; it must be grasped future career development through education. So poor college students do in school self-analysis stage, understand their career interests and expertise, to form their own professional values, to plan their long-term and short-term development goals, to improve their ability, and then to form their own specific career development planning, and to enhance self-esteem, self-confidence.

\section{B. Construction of Integrated Funding System of Aid Funds, Wisdom Aid and Ability Aid}

As previously analyzed, what the poor students in universities are facing often is not simply the current economic difficulties; the relationship includes the relationship of face between material resources, knowledge of technical information, people and social institutions. This is a relationship when one person or a group have lost or have been denied, so he could not get those resources to meet their basic needs. They cannot afford to manage and mobilize these resources, this time we say he is poor or will become poor ...... simply helping individuals from the economy cannot solve this problem, it is important that they get the resources to improve the capabilities and possibilities. "Therefore, for the poor students of the University, building poor funding system should also be funded aid, wisdom and ability to help enhance integration.

The existing system of poor students funds in universities focus on solving the economic problems of poverty. On the whole, this funding is effective, but it often is temporary, so in addition to the existing funding system, the University of poor students can try the integrated design the funding system, the base path established livelihood security of funding to enhance the development of funded academic ability, mental health funding guiding one of the funded projects. That is, for the funding of the current poor college students, the project is to integrate, and the formation of life, academic ability and psychological aid money go three categories. Funding for the life of poor students with college bounds student campus card and solves basic monthly living allowance. Both are to limit abuse and misappropriation subsidy funds of students. It is also to ensure the physical health of students and academic capacity building funding. You can use the trial to open for the community tender Mandarin, computers, English and focus on practical ability and professional, occupational general ability of the project to allow poor students to establish confidence in learning aspects of employment (career development). it does not lose at the starting point, at the same time to guide and adaptation of poverty due to lack of confidence caused by too introverted and mental depression, mental health can be used to set up a special project funding, expand training and other aspects of the project; solve problems to worry about graduation.

We should help build capital to help the integration fund aid, wisdom aid and ability aid of university funding system for poor students who should also aid the second-class universities, community activities support activities. It can not only reduce costs and time costs money to run a number of projects, and to facilitate the organization. You can also let the poor students on campus be familiar with classmates' in-depth interaction, to enhance friendship and recognition, to create a good atmosphere to grow, to help them better integrate into university life.

\section{Build Service-learning Platform and Establish Funding Evaluation, Accountability and Feedback Mechanisms}

Poor students of the University Grants system are to create the conditions for them when entering the professional and social fields. They have a better starting point, but this should not be a dependent on funding, but it should not be a free ride for a "handout" but the current funding onedimensional "gift". So it does not require the University of poor students to bear too much responsibility, but it also led to a lot of self-control that is not strong students with less 
funding available to meet their essential material needs. Therefore, the establishment of service-learning platform is to help poor college students with the ability to not only exercise, but also enhance the sense of responsibility and citizenship.

Service learning (Service-learning, SL) is educational philosophy and practices in the late 1980s in the United States, it is first used in teacher training activities, academic learning and community service will combine together, more than a dozen years of rapid development, as an important way to apply a wide range of personnel training in American universities. For poor students in universities, the establishment of service-learning platform is to help "students have clear learning objectives, and in the service of what we've learned during the conduct of organized service activities positive reflection. Service learning students and classroom learning real social problems need to be combined, not only to promote the intellectual development of students, also to promotes civic participation of students. in addition, from the University of poor management point of view, poverty application and poor students should have self goal setting, combined with funding target, forming a sponsor evaluation, feedback, and improve the system to promote student while obtaining funding. It is responsible for funding the cost of obtaining and shows their achievements in the progress and development funding will allow poor students to gain skills, and to produce confidence.

\section{Leading Poor Students to Self-help}

A change of a person from facing difficulties from outside is certainly contributing factor effect, but ultimately his own self is indivisible. For poor students in universities, the final "turnaround" should be made to achieve through his own efforts, which is the most effective and lasting. So, guiding self-help of poor students in universities is an important component in university funding system.

A survey conducted by the University shows that learning hard and the University of Poor Students generally characterizes hard work. But the plight of the economy, poor students are prone to two undesirable phenomena: First, it is prone to have low self-esteem and psychological closure, the second is the lack of social responsibility with attention to immediate interest, they are prone to compete for limited scholarships or bursaries indicators. Therefore, workers of the university student management should pay attention to cultivate self-awareness and the ability of poor students, which is the most important part of funding from Aid funding to wisdom aid in the University of Poverty. First, it should help poor students of the University through their own labor and efforts address the economic, psychological problems in life itself exists in real will, they can put it into action. Secondly, it should be through project-based training to help them acquire skills or master the psychology of selfadjustment of the ways that means to achieve them through their own efforts to achieve the goal of self-help. Finally, in the whole society, universities and family should express their willingness to help self-understanding, support, and provide assistance and conditions. So, they can have selfpractice. Interested parties should be through the establishment of self-help positions, practice self-help, selfhelp programs for poor students to master the Church towards the knowledge and skills needed for the poor. Of course, the concern of poor students in psychology, and other realities of life are among the various problems and difficulties, which is to give appropriate assistance and guidance at the crucial moment that is still the primary responsibility of your university.

\section{CONCLUSION}

Rawls' Theory of "Justice "mentions that: in all parts of society, every person has a similar motivation and endowments, it should have roughly equal access to education and achievement prospects. Those who have the same abilities and aspirations should not be influenced by their social origins. So it is a responsibility for the University of the whole society to help poor students incumbent. But the fund only apparently is insufficient for the co-funded universities to help poor students get out of real "turnaround", only oriented to people (poor college students) is as the first hero and as the ultimate goal of development, the University of poor students will really bring the essence of change. In the past, the capital funding for individual care management mainly goes around the core funding to help wisdom management. They are more inclined to focus on the overall focus, and its focus is to help universities to improve the overall capacity to respond to the problem of poor students. In addition to addressing poor college students and learning life issues, from learning for employment and other aspects of life from the psychological to the systematic training for poor students and university culture, it includes cultivating the interpersonal relationship, social services and the ability to develop other aspects of their future careers.

\section{ACKNOWLEDGEMENTS:}

[Fund]: Jiangsu Provincial Department of Education Philosophy and Social Science Fund Project Name: University of organic link with the secondary research, project number: 2010SJD880044; Nanjing "five" Educational Planning Project Name: Nanjing Social Service Capacity of Local Colleges the Present Situation and development Research project Number: LQ / 2011/002

\section{References}

[1] Zhang Rensong. Build - "self-funded" integrated rescue mode [J] Education and career, in 2013 the first one (in) poor college students.

[2] Ji Feng. Poor College Students demand for subsidized Perspective [J]. Education Review, 20124

[3] Zhang Liguo, Yan Shaqing. Subsidization for poor students to improve people-oriented system in the visual field [J]. Higher Studies, 20108

[4] Xia Xinping. Innovation [J] funding model based on poor college students in social work. Education and Vocational .2012 First 29 